Penelitian

\title{
Performa Sapi Simmental yang Diberi Imbuhan Selenium dan Zink dalam Pakan
}

\author{
Asep Kurnia ${ }^{1^{*}}$, Soeparna ${ }^{2}$, lis Arifiantini ${ }^{3^{*}}$, Rahmat Hidayat ${ }^{4}$ \\ ${ }^{1}$ Fungsional Balai Inseminasi Buatan, Lembang \\ ${ }^{2}$ Laboratorium Reproduksi Ternak dan Inseminasi Buatan, Fakultas Peternakan, \\ Universitas Padjajaran, Indonesia \\ ${ }^{3}$ Divisi Reproduksi dan Kebidanan, Departemen Klinik, Reproduksi dan Kebidanan, Fakultas Kedokteran Hewan, \\ Institut Pertanian Bogor, Indonesia \\ ${ }^{4}$ Laboratorium Nutrisi Ternak Ruminansia dan Kimia Makanan Ternak, Fakultas Peternakan, \\ Universitas Padjajaran, Indonesia \\ *Penulis untuk korespondensi: iis.arifiantinipurna@gmail.com, asep_kurnia99@yahoo.com \\ Diterima 14 Juli 2019, Disetujui 13 Januari 2020
}

\begin{abstract}
ABSTRAK
Manajemen pakan pejantan sapi sangat penting di Balai Inseminasi Buatan (BIB). Beberapa mineral dilaporkan sangat penting dalam proses reproduksi pejantan. Penelitian ini bertujuan untuk menguji performa sapi pejantan Simmental yang diberi imbuhan zink (Zn) dan Selenium (Se). Delapan belas ekor pejantan Simmental umur 7 tahun, milik BIB Lembang digunakan dalam penelitian ini. Pejantan dibagi tiga kelompok masing-masing 6 ekor. Kelompok I (R1) diberi pakan standar, kelompok II (R2) diberi pakan Standar dan imbuhan Zn dan Se minimal dan kelompok III (R3) diberi pakan Standar dan imbuhan Zn dan Se maksimal selama 60 hari. Parameter yang diukur adalah pertambahan berat badan harian (PBBH), pertumbuhan kuku dan libido. Data awal dan akhir penelitian dibandingkan dengan Student $\mathrm{T}$ test dan data disampaikan dalam rerata \pm SEM. Hasil penelitian menunjukkan imbuhan $\mathrm{Zn}$ dan Se dapat mempertahankan berat badan sapi Simmental, dan tidak ada perbedaan PBBH antar pakan yang diberikan. Pertumbuhan kuku dan libido juga tidak dipengaruhi oleh mineral yang diberikan.
\end{abstract}

Kata kunci: Sapi Simmental, Zink, Selenium, PBBH, libido

\begin{abstract}
Management of bull feeding is very important at Artificial Insemination Center (AIC). Some minerals are reported to be important in the reproduction process of males. This study aims to evaluate the performance of Simmental bulls after supplementation with zink (Zn) and Selenium (Se). Eighteen Simmental bulls ages 7 year old, belong to AIC Lembang, were used in this study. The bulls were divided into three groups, 6 head each. Group I (R1) was given with standard feed, group II (R2) was fed with standard and supplemented with Zn and Se minimum and group III (R3) was fed with standard feed and supplemented with $\mathrm{Zn}$ and Se maximum for 60 days. Parameters were measured of average daily gain weight $(A D G)$, hoove growth and libido. Data before and after treatment were compared with Student $T$ test and data were presented in mean \pm SEM. The results show that $\mathrm{Zn}$ and Se can maintain Simmental body weight, and there were no difference between ADG before and after feeding. The hoove growth and libido were also not influenced by supplementation of both mineral.
\end{abstract}

Keywords: Simmental bull, Zinc, Selenium, ADG, libido 


\section{PENDAHULUAN}

Semen beku yang dihasilkan di Balai Inseminasi Buatan (BIB), harus berasal dari sapi dengan genetik yang unggul dan sehat. Sapi-sapi tersebut dipelihara dengan manajemen pemeliharaan pejantan meliputi sistem perkandangan, formulasi dan pemberian pakan, penanganan kesehatan termasuk pemeliharaan pemotongan kuku dan exercise. Exercise menurut Rahmawati et al. (2015) pada sapi peranakan ongole (PO) tidak memperbaiki kualitas semen, exercise selama 1 dan 2 jam seminggu tiga kali cenderung menurunkan libido.

Sapi Simmental merupakan sapi dwiguna (dual purpose) mempunyai produksi susu yang baik serta produksi daging yang tinggi, karena menghasilkan karkas yang tinggi dengan sedikit lemak. Sapi Simmental mempunyai sifat jinak, tenang, dan mudah dikendalikan (Susilorini 2008). Dirjen PKH melalui Direktorat Pakan, menghimbau agar setiap Unit Pelaksana Teknis (UPT) mencanangkan swasembada pakan. Swasembada pakan tersebut melalui program penambahan lahan untuk pemenuhan hijauan makanan ternak (HMT) dan pembuatan konsentrat secara mandiri. Pembuatan pakan sendiri diharapkan akan lebih ekonomis dan akan menghilangkan ketergantung pada pakan produksi dari pabrik.

Beberapa peneliti memberikan imbuhan mikromineral pada pakan seperti Zink (Zn) dan Selenium (Se). Pradhan dan Nakagoshi (2008) menyatakan bahwa Zn merupakan salah satu mineral yang berperan dalam proses reproduksi jantan. Mineral ini terlibat dalam beberapa reaksi metabolisme karbohidrat, sintesis protein dan metabolisme asam nukleat (Miller 1970). Mineral Zn menstimulir sel leydig pada testes untuk memproduksi testosteron karena mineral ini merupakan komponen protein yang terlibat dalam sintesis dan sekresi testosteron (Ebisch et al. 2003). Kumar et al. (2006) menyatakan pemberian $\mathrm{Zn}$ anorganik maupun $\mathrm{Zn}$ organik dapat meningkatkan kualitas dan kuantitas semen sapi. Zink menurut Cheah dan Yang (2011) berperan dalam sistem reproduksi jantan, di antaranya berperan dalam aktifitas enzim ribonuclease yang sangat tinggi dalam proses mitosis spermatogonia dan meiosis.

Selenium (Se) berperan sebagai antioksidan yang mampu mencegah kerusakan kromosom dan menjaga kesuburan. Selenium merupakan key element dalam spermatogenesis and fertilitas jantan (Boitani dan Puglisi 2008). Selenium dapat meningkatkan jumlah spermatid, terutama bekerja dalam merubah spermatosit dalam pembelahan meosis ke dua untuk membentuk spermatid (Ganabadi et al. 2010).
Perawatan dan pemotongan kuku merupakan bagian penting dalam manajemen pejantan penghasil semen di BIB. Pemotongan kuku harus dilakukan secara teratur sehingga beban berat badan dan kuku selalu seimbang dan proporsional. Faktor yang memengaruhi pertumbuhan kuku di antaranya adalah jenis dan bangsa ternak, pakan dan alas kandang (Telezhenko dan Bergsten 2005). Selain kuku, berat badan sapi pejantan juga harus diperhatikan. Pejantan yang baik tidak boleh terlalu gemuk dan tidak boleh kurus (Permadi et al. 2013). Body Condition Score (BCS) ideal untuk sapi pejantan menurut Permadi et al. (2013) adalah antara 5-7 dalam skala 1 (sangat kurus) -9 sangat gemuk, BCS sedang adalah (4), dan gemuk jika nilai BCS 8-9.

Libido sangat penting untuk pejantan. Libido tidak secara langsung berhubungan dengan kualitas semen namun berpengaruh terhadap kecepatan koleksi semen dan memengaruhi kecepatan produksi semen beku. Balai IB nasional memproduksi semen beku perhari sekitar 60 sampai dengan 80 ekor, sehingga dibutuhkan pejantan yang mempunyai libido yang tinggi. Pentingnya pakan dalam menunjang produktivitas pejantan dan kondisi kuku, berat badan dan libido akan memengaruhi kemampuan pejantan dalam menghasilkan semen segar, maka penelitian ini bertujuan untuk menganalisis imbuhan mineral Se dan Zn terhadap pertambahan berat badan, pertumbuhan kuku dan libido sapi Simmental di BIB Lembang.

\section{BAHAN DAN METODE}

Penelitian ini dilaksanakan pada bulan Agustus sampai Oktober Tahun 2016 di Balai Inseminasi Buatan Lembang dan Laboratorium Nutrisi Pakan Universitas Padjadjaran.

\section{Ternak Percobaan}

Sebanyak 18 ekor pejantan Simmental berumur 7 tahun, dikandangkan secara individu ukuran 2,5 x 4 m. Sapi dibagi menjadi tiga perlakuan pakan masing-masing 6 ekor. Kelompok pertama diberi pakan standar (R1) kelompok kedua diberi pakan yang diberi imbuhan Se dan Zn minimalis ( $R_{2}$ ) dan kelompok ketiga diberi pakan yang diberi imbuhan Se, Mn, dan Zn maksimal (R3). Pakan perlakukan diberikan selama 60 hari (satu siklus spermatogenesis). Komposisi pakan disajikan pada Tabel 1. 
Tabel 1 Komposisi pakan perlakuan

\begin{tabular}{|c|c|c|c|}
\hline \multirow{2}{*}{ Bahan } & R1 Standar & $\mathrm{R} 2$ & R3 \\
\hline & \multicolumn{3}{|c|}{ 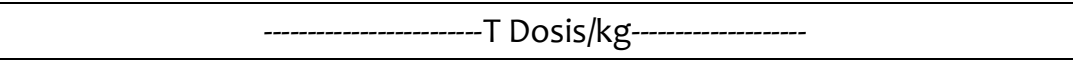 } \\
\hline BK & 13.96 & 13.96 & 13.96 \\
\hline TDN & $7 \cdot 3$ & 8.2 & $7 \cdot 3$ \\
\hline PK & 1.227 & 2.63 & 1.227 \\
\hline $\mathrm{Ca}$ & 0.041 & 0.133 & 0.041 \\
\hline $\mathrm{F}$ & 0.025 & 0.066 & 0.025 \\
\hline $\mathrm{Mn}$ & 0.00035 & 0.00035 & 0.00035 \\
\hline $\mathrm{Zn}$ & 0 & 0.001 & 0.002 \\
\hline Se & 0 & 0.003 & 0.007 \\
\hline
\end{tabular}

Keterangan: (BK,TDN,PK,Ca,F) NRC. Zn= 10-50 mg/kg, Se= 0,05-0,3 ppm, T = total pakan dalam kilogram

Pertambahan Berat Badan Harian (PBBH).

Penilaian PBBH dilakukan dengan mengukur berat pejantan dengan menggunakan tempat penimbangan ternak yang dilengkapi dengan timbangan digital (Cas) dengan ketelitian $0,5 \mathrm{~kg}$ pada awal dan akhir penelitian.

\section{Pertumbuhan Kuku}

Kuku sapi dipotong menggunakan renet dalam waktu yang bersamaan. Pertumbuhan kuku dilakukan dengan mengukur kuku pejantan pada awal dan akhir penelitian menggunakan jangka sorong, panjang kuku dinyatakan dalam milimeter. Pengukuran kuku dilakukan pada awal dan akhir penelitian.

\section{Pola Kopulasi/Libido}

Penilaian libido dilakukan dengan mengamati dan mengklasifikasikan tingkah laku pejantan dalam kopulasi. Libido dinilai dalam waktu (menit) yang diperlukan sejak mulai courship, ereksi, protrusi, mounting, intromisi, ejakulasi sampai sapi jantan turun dari betina. Libido diamati setiap minggu sekali, namun data disampaikan pada sebelum dan sesudah perlakuan.

\section{Analisis Data}

Data yang diperoleh dari pengamatan PBBH dan pertumbuhan kuku dan libido dianalisis dengan Student $T$ test, menggunakan program SPSS. Data disajikan dalam bentuk mean \pm Standard Error of Mean (SEM).

\section{HASIL DAN PEMBAHASAN}

Pengaruh Pemberian Imbuhan $\mathrm{Zn}$ dan Se terhadap Pertambahan Berat Badan Harian (PBBH) Sapi Simmental

Berat badan sapi Simmental sebelum dan sesudah perlakuan disajikan pada Tabel 2. Tabel 2, menunjukkan berat badan pada saat penimbangan, sebelum penelitian berkisar antara $940 \mathrm{~kg}$ sampai dengan 1070 kg. Rerata pada awal penelitian untuk R1 adalah 995 $\pm 19,58 \mathrm{~kg}, \mathrm{R} 2$ adalah $1001 \pm 22,46 \mathrm{~kg}$ dan R3 adalah $1009 \pm 36,00 \mathrm{~kg}$. Akhir penelitian menunjukkan berat badan antara 880 sampai dengan $1080 \mathrm{~kg}$, dengan rerata berat badan pada akhir penelitian, untuk R1, R2 dan R3 masing-masing adalah $980 \pm 15,1 \mathrm{~kg}$, $985 \pm 23,22 \mathrm{~kg}$ dan $1018 \pm 36,10 \mathrm{~kg}$. Berat badan sapi Simmental masih dalam kondisi normal sesuai dengan pendapat Sugeng (1998), karena berat badan pejantan Simmental dapat mencapai $1.150 \mathrm{~kg}$.

Tidak terdapat perbedaan berat badan antar semua perlakuan, berat badan sapi dalam penelitian ini masih di bawah rerata berat badan yang dikeluarkan sebagai standar pejantan oleh Association of Slovak Spotted Cattle Breeders - Cooperative (2014) yaitu berat untuk pejantan dengan umur 5 (lima) tahun lebih adalah $1200 \mathrm{~kg}$. Dengan membandingkan rerata berat badan dan standar pejantan pada umumnya, maka pejantan Simmental pada penelitian ini dianggap dapat menghasilkan kualitas semen yang baik.

Pertambahan berat badan harian adalah besarnya pertambahan berat badan yang dipengaruhi oleh besarnya selisih antara berat badan awal dan berat badan akhir. Berdasarkan lamanya pemeliharaan atau selisih waktu penimbangan (hari). Data pertambahan rerata berat badan harian disajikan dalam Tabel 3 . 
Tabel 2 Berat badan sapi Simmental sebelum dan sesudah pemberian pakan yang diberi imbuhan Zn dan Se (rerata \pm SEM)

\begin{tabular}{|c|c|c|c|}
\hline Pakan & No Pejantan & Awal (kg) & Akhir (kg) \\
\hline \multirow{6}{*}{$\mathrm{R} 1$} & 60987 & 985 & 990 \\
\hline & 60986 & 940 & 965 \\
\hline & 609104 & 950 & 955 \\
\hline & 609106 & 1070 & 1060 \\
\hline & 609107 & 1020 & 1003 \\
\hline & 60990 & 1005 & 985 \\
\hline Rerata & & $995 \pm 19,58$ & $980 \pm 15,1$ \\
\hline \multirow{6}{*}{$\mathrm{R} 2$} & 609108 & 995 & 978 \\
\hline & 60982 & 998 & 987 \\
\hline & 609109 & 900 & 880 \\
\hline & 60994 & 1050 & 1034 \\
\hline & 60991 & 1010 & 995 \\
\hline & 609111 & 1050 & 1036 \\
\hline Rerata & & $1001 \pm 22,46$ & $985 \pm 23,22$ \\
\hline \multirow{6}{*}{$\mathrm{R}_{3}$} & 60981 & 987 & 994 \\
\hline & 60988 & 985 & 995 \\
\hline & 609110 & 980 & 990 \\
\hline & 60992 & 1035 & 1042 \\
\hline & 60985 & 1070 & 1080 \\
\hline & 60999 & 995 & 1004 \\
\hline Rerata & & $1009 \pm 36,00$ & $1018 \pm 36,10$ \\
\hline
\end{tabular}

Keterangan: R1= Pakan standar, R2= Pakan dengan imbuhan Zn dan Se minimal, R3= Pakan dengan imbuhan Zn dan Se maksimal

Rerata PBBH (Tabel 3) yaitu - 0,29 kg untuk perlakuan R1, - 0,04 kg untuk R2 dan 0,05 kg untuk R3. Pertambahan berat badan harian untuk perlakuan R1 dan R2 terlihat negatif atau terjadi penurunan. R1 atau ransum standar berupa hijauan $50 \mathrm{~kg}$ dengan $0,6 \mathrm{~kg}$ hay ditambah konsentrat $5 \mathrm{~kg}$. R2 adalah ransum standar yang diimbuh dengan $1 \mathrm{~g}$ Se dan $2 \mathrm{~g}$ Zn, sedangkan R3 diberi ransum standar dan diimbuh $7 \mathrm{~g}$ Se dan $3 \mathrm{~g} Z \mathrm{Zn}$. Pada perlakuan ini terjadi penambahan berat badan harian sebesar 0,05 kg. PBBH pada penelitian ini jauh lebih rendah apabila dibandingkan dengan PPBH sapi Simmental Cross pada masa pertumbuhan. Jika telah disilangkan sapi peranakan Simmental mempunyai pertambahan berat badan berkisar antara 0,6 sampai 1,5 kg/hari (Hadi 2002).

Penurunan atau peningkatan berat badan harian yang rendah terjadi disebabkan sapi pejantan Simmental pada penelitian ini sudah berumur 7 (tujuh) tahun sehingga sudah melewati masa pertumbuhan. Menurut Siregar (2008) pertumbuhan yang cepat terjadi pada periode lahir hingga usia penyapihan dan pubertas, namun setelah usia pubertas hingga usia dewasa, laju pertumbuhan mulai menurun dan akan terus menurun hingga usia dewasa. Pada usia dewasa, pertumbuhan sapi berhenti. Proses pertumbuhan pada ternak sapi dimulai sejak awal terjadinya pembuahan sampai dengan pedet itu lahir, dilanjutkan hingga sapi menjadi dewasa (Sugeng, 1998).

Tidak ada perbedaan yang nyata pada PBBH dalam penelitian ini kemungkinan disebabkan oleh pakan hijauan dan konsentrat dengan kandungan zatzat gizi berupa karbohidrat, protein dan vitamin yang diberikan memiliki volume bahan kering yang sama. Mineral Zn dan Se minimal ataupun maksimal tidak secara langsung memengaruhi berat badan sapi.

Penurunan berat badan ini merupakan langkah yang dianggap tepat dengan tujuan menurunkan berat badan pada pejantan yang cenderung kegemukan. Kegemukan dapat menjadi penyebab menurunnya produktivitas pejantan penghasil semen. Menurut Sugeng (2003), penimbunan lemak terjadi sesudah hewan mencapai kedewasaan tubuh, yakni sesudah pertumbuhan jaringan tulang dan otot selesai. Kegemukan juga dapat menyebabkan terjadinya gesekan timbunan lemak pada scrotum. 
Tabel 3 Pertambahan Berat Badan Harian (PBBH) Sapi Simmental setelah pemberian pakan yang diberi imbuhan Zn dan Se

\begin{tabular}{cccc}
\hline Ulangan & \multicolumn{3}{c}{ Perlakuan } \\
\cline { 2 - 4 } & $\mathrm{R} 1$ & $\mathrm{R} 2$ & $\mathrm{R} 3$ \\
\hline 1 & -0.08 & -0.58 & -0.95 \\
2 & 0.08 & -0.05 & 0.58 \\
3 & -1.17 & -0.42 & 0.08 \\
4 & 0.08 & -0.33 & 0.58 \\
5 & 0.42 & 0.17 & -1 \\
6 & -1.08 & 1 & 1 \\
\hline Rerata & $-0.29 \mathrm{a}$ & $-0.04 \mathrm{a}$ & $0.05 \mathrm{a}$
\end{tabular}

Keterangan: R1= Pakan standar, R2= Pakan dengan imbuhan Zn dan Se minimal, R3= Pakan dengan imbuhan Zn dan Se maksimal Huruf yang sama mengikuti angka pada baris yang sama menyatakan tidak berbeda nyata $p>0.05$

Gesekan tersebut akan meningkatkan suhu testis yang dapat mengganggu thermoregulasi testes sehingga berakibat pada penurunan produksi sperma dan kualitas semen (Coulter dan Kozub 1989).

\section{Pengaruh Imbuhan Zn dan Se dalam Pakan ter- hadap Pertumbuhan Kuku Sapi Simmental}

Kondisi kuku sapi pejantan sangat penting. Kuku yang tidak sehat akan mengganggu pergerakan sapi tersebut, kuku yang panjang akan mengganggu saat mounting. Panjang kuku pejantan Simmental pada awal penelitian dilakukan pada waktu yang hampir bersamaan. Setelah dua bulan pertumbuhan kuku diukur dan selisih panjang kuku sebelum dan sesudah perlakukan disajikan pada Tabel 4.

Panjang kuku berkisar antara $76.13 \mathrm{~mm}$ sampai dengan $87.75 \mathrm{~mm}$ untuk keempat kaki depan dan belakang. Panjang kuku ini mendekati panjang kuku kaki normal karena posisi berdiri ke-empat kuku sapi dapat berdiri tegak dengan posisi 45 derajat. Posisi tersebut memungkinkan pejantan dapat melakukan aktivitas seperti berjalan, tidur dan mounting dengan nyaman.

Tabel 4 menunjukkan tidak terdapat selisih panjang kuku pada sapi Simmental yang diberi tiga jenis ransum berbeda. Imbuhan mineral Se dan $\mathrm{Zn}$ ini harus terus dikaji sehingga dapat ditemukan formulasi pakan yang dapat menjaga kesehatan kuku dan mendukung pertumbuhan serta daya tahan yang maksimal terhadap serangan penyakit kuku. Kuku yang sakit dapat menurunkan kemampuan mounting dan libido sehingga menurunkan produktivitas sapi tersebut (Radisic et al. 2012). Prinsip pemotongan kuku dengan mengembalikan kuku kepada bentuk yang ideal, mengurangi rasa nyeri akibat ketidakseimbangan penyebaran tumpuan berat badan dan membuang tulang mati sehingga dapat merangsang pertumbuhan tulang baru adalah hal yang paling penting dalam pemotongan kuku (Stoddard dan Cramer 2017).

Pengaruh Imbuhan Zn dan Se dalam Pakan terhadap Libido Sapi Simmental

Libido adalah keinginan ternak untuk kopulasi. Libido diukur dengan membandingkan lama waktu (menit) mulai courship (percumbuan) sampai ejakulasi. Pengklasifikasian tingkat libido pada penelitian ini sesuai SOP produksi semen BIB Lembang, terbagi 3 tingkatan yaitu, libido dengan waktu $<5$ menit termasuk tinggi, 5-15 menit, sedang dan $>15$ menit termasuk libido rendah. Libido sapi pejantan Simmental sebelum dan sesudah imbuhan mineral Se dan Zn disajikan pada Tabel 5 .

Penilaian libido dalam penelitian ini dengan cara mengukur lama waktu pejantan Simmental tersebut mulai courship sampai dengan ejakulasi. Libido sapi pejantan Simmental sangat bervariasi. Sapi-sapi yang diberi R1 menunjukkan lama waktu mulai courship sampai ejakulasi sebelum dan sesudah perlakuan adalah 5,84 $\pm 1,18$ dan 5,02 $\pm 0,76$ menit. Sapi yang diberi R2 menunjukkan lama waktu dari courship sampai ejakulasi masing-masing $11,39 \pm 1,80$ dan $8,72 \pm 0,81$ dan yang diberi $R 3$ adalah 10,70 $\pm 2,45$ dan 7,66 $\pm 1,57$ menit. Tidak terdapat perbedaan antara sebelum dan sesudah perlakukan pada tiga jenis ransum yang diberikan. 
Tabel 4 Selisih pertumbuhan kuku sapi Simmental sebelum dan sesudah pemberian pakan yang diberi imbuhan Zn dan Se (rerata \pm SEM)

\begin{tabular}{ccccc}
\hline & & \multicolumn{3}{c}{ Perlakuan pakan } \\
\cline { 3 - 4 } & Ulangan & R1 & R2 & R3 \\
\cline { 3 - 5 } & 1 & 4,76 & Selisih panjang kuku (mm) & 6,73 \\
& 2 & 4,69 & 5,86 & 6,89 \\
& 3 & 7,51 & 5,00 & 6,75 \\
& 4 & 7,8 & 5,51 & 3,26 \\
& 5 & 7,68 & 6,18 & 3,39 \\
\hline Rerata & 6 & 7,63 & 5,81 & 3,43 \\
\hline
\end{tabular}

Keterangan: R1= Pakan standar, R2= Pakan dengan imbuhan Zn dan Se minimal, R3= Pakan dengan imbuhan Zn dan Se maksimal Huruf yang sama mengikuti angka pada baris yang sama menyatakan tidak berbeda nyata $(p>0.05)$

Tabel 5 Rerata libido (menit) pejantan Simmental sebelum dan sesudah pemberian pakan yang diberi imbuhan Zn dan Se (rerata \pm SEM)

\begin{tabular}{cccc}
\hline Pakan & No Pejantan & Sebelum (menit) & Sesudah (menit) \\
\hline & 60987 & 3,82 & 4,17 \\
R1 & 60986 & 5,06 & 1,49 \\
& 609104 & 3,89 & 3,27 \\
& 609106 & 4,49 & 8,38 \\
Rerata & 609107 & 10,61 & 5,20 \\
\hline & 60990 & 5,15 & $5,02 \pm 1,03 a$ \\
R2 & 609108 & $5,50 \pm 1,05 a$ & 6,27 \\
& 60982 & 12,29 & 16,24 \\
& 609109 & 17,28 & 4,7 \\
Rerata & 60994 & 6,7 & 6,19 \\
& 60991 & 5,31 & 13,81 \\
& 609111 & 19,29 & 5,1 \\
\hline R3 & 60981 & 7,47 & $8,72 \pm 2,03 a$ \\
& 60988 & $11,39 \pm 2,39 a$ & 14,1 \\
& 609110 & 20,3 & 2,4 \\
\hline Rerata & 60992 & 3,49 & 7,09 \\
\hline
\end{tabular}

Keterangan: R1= Pakan standar, R2= Pakan dengan imbuhan Zn dan Se minimal, R3= Pakan dengan imbuhan Zn dan Se maksimal Huruf yang sama mengikuti angka pada baris yang sama menyatakan tidak berbeda nyata $p>0.05$

Tidak berbedanya lama waktu antara courship ke ejakulasi disebabkan kerena pengaruh individu yang sangat besar. Kisaran libido pada sapi-sapi kelompok pakan R1 sebelum perlakuan pakan adalah dari 3,82 sampai 10,61 menit, setelah perlakuan pakan 1,49 sampai dengan 8,38 menit. Variasi kisaran libido pada kelompok sapi yang diberi ransum R2 sebelum perlakuan tercepat adalah 5,31 menit dan terlama 17,28 menit. Sesudah perlakuan menunjukkan kisaran nilai hampir sama yaitu tercepat 5,10 dan terlama adalah 16,24 menit. Sapi yang diberi R3 sebelum perlakukan mempunyai kisaran 2,87 sampai 20,30 menit dan setelah perlakuan adalah 2,40 sampai 14,10 menit.

Selang waktu yang sangat panjang antar individu tersebut menyebabkan tidak berbedanya antara ransum yang diberikan sesudah perlakuan. Libido dipengaruhi oleh konsentrasi testosteron. Neek et al. (2011), meneliti pengaruh pemberian selenium, $\mathrm{Zn}$ dan kombinasi $\mathrm{Zn}$ selenium pada manusia, terhadap 
kadar testosteron darah. Hasilnya ternyata pemberian $\mathrm{Zn}$ tunggal lebih baik dibandingkan selenium tunggal atau kombinasi Se dan Zn.

Libido sapi Simmental sebelum dan sesudah perlakuan penambahan imbuhan mineral selenium dan Zn menunjukkan kisaran normal. Menurut Petherick (2003) bahwa pada seleksi pejantan kisaran libido normal untuk bos taurus kisarannya adalah 10 menit dan untuk bos indicus selama 20 menit. Tingkat libido individu pejantan tidak menggambarkan kualitas semen yang dihasilkan (Singh et al. 2015), namun menentukan kecepatan waktu proses produksi. Sapi jantan yang mempunyai libido yang tinggi akan menghasilkan ejakulat yang dalam waktu cepat, otomatis akan mempercepat proses produksi semen beku. Penelitian ini juga membuktikan bahwa imbuhan mineral makro selenium dan $\mathrm{Zn}$ dianggap cukup, sehingga tidak memengaruhi lama waktu ejakulasi.

Menurut Suprijati (2013), unsur Zn sangat diperlukan untuk menjaga dan memperbaiki metabolisme dalam tubuh berperan dalam proses reproduksi jantan, dalam beberapa reaksi metabolisme karbohidrat, sintesis protein dan metabolisme asam nukleat (Pradhan dan Nakagoshi 2008). Mineral Zn menstimulir sel leydig pada testes untuk memproduksi testosteron karena mineral ini merupakan komponen protein yang terlibat dalam sintesis dan sekresi testosteron (Ebisch et al. 2003). Penelitian ini tidak membuktikan peranan $\mathrm{Zn}$ dalam meningkatkan libido, pejantan yang diberi $\mathrm{R} 2$ dan $\mathrm{R} 3$ tidak lebih baik dibandingkan yang diberi R1. Libido selain dipengaruhi testosteron, juga dipengaruhi waktu koleksi dan lingkungan tempat koleksi semen dilakukan (Petherick 2005)

Mineral mikro dibutuhkan hanya dalam jumlah kecil, apabila termakan dalam jumlah besar dapat bersifat racun (Widodo 2002). Keracunan mineral memengaruhi produksi, yaitu penurunan berat badan, hambatan pertumbuhan, peka terhadap penyakit infeksi, dan kematian. Di samping itu, residu mineral (logam) dapat menurunkan kualitas produk ternak (Darmono 2001).

Imbuhan Zn dan Se dalam konsentrasi minimal atau maksimal dalam penelitian ini terbukti dapat mempertahankan berat badan ideal sapi, tidak memengaruhi kecepatan tumbuh kuku sapi dan tidak memengaruhi libido. Balai IB dapat memilih memberikan imbuhan mineral atau tidak ke dalam pakannya. Imbuhan $\mathrm{Zn}$ dan Se perlu diuji terhadap kualitas semen segar dan juga terhadap kualitas semen beku
"Penulis menyatakan tidak ada konflik kepentingan dengan pihak-pihak yang terkait dalam penelitian ini".

\section{DAFTAR PUSTAKA}

Boitani C, Puglisi R. 2008. Selenium, a key element in spermatogenesis and make fertility. Molecular Mechanisms in Spermatogenesis. Advances in Experimental Medicine and Biology. 636: 65-73

Cheah Y, Yang W. 2011. Functions of essential nutrition for high quality spermatogenesis. Advances in Bioscience and Biotechnology. 2: 182-197

Coulter GH, Kozub GC. 1989. Efficacy of methods to test fertility of beef bulls used for multiple-sire breeding under range conditions. Journal of Animal Science. 67: 1757.

Darmono. 2001. Lingkungan Hidup dan Pencemaran. Hubungannya dengan Toksikologi Senyawa Logam. Jakarta (ID): Penerbit Universitas Indonesia (UI Press). hlm. 109-111.

Ebisch IM, Van Heerde WL, Thomas CM, Van Der Put N, Wong WY, Steegers-Theunissen RP. 2003. C677T methylenetetrahydrofolatereductase polymorphism interferes with the effects of folic acid and zinc sulfate on sperm concentration. Fertility and Sterility. 80: 11901194.

Ganabadi S Jr, Halimatun Y, Choong KLA, Nor JA, Hilmi MA. 2010. Effect of selenium supplementation on spermatogenic cells of goats. Malaysian Journal of Nutrition. 16(1): 187-193.

Hadi PU, Ilham N. 2000. Peluang Pengembangan Usaha Pembibitan Ternak Sapi Potong di Indonesia Dalam Rangka Swasembada Daging 2005. Bogor (ID): PSE.

Kumar N, Verma RP, Singh LP, Varshney VP, Dass RS. 2006. Effect of different levels and sources of zinc supplementation on quantitative and qualitative semen attributes and serum testosterone level in crossbred cattle (Bos indicus $\times$ Bos taurus) bulls. Reproduction Nutrition. Development. 46: 663-675.

Miller WJ. 1970. Zinc Nutrition of Cattle: A Review. Journal of Dairy Science. 53(8):1123-1135

Neek LS, Gaeini AA, Choobineh, S. 2011. Effect of Zinkc and Selenium Supplementation on Serum Testosterone and Plasma Lactate in Cyclist after an Exhaustive Exercise bout. Biological Trace element research. 144: 454-462. 
Permadi DS, Tagama TR, Yuwono P. 2013. Produksi semen segar dan semen beku sapi pejantan dengan body condition score (BCS) yang berbeda di balai inseminasi buatan lembang. Jurnal IImiah Peternakan. 1(3): 759-767.

Petherick JC. 2005. A review of some factors affecting the expression of libido in beef cattle, and individual bull and herd fertility. Applied Animal Behaviour Science. 90 (3-4): 185-205

Pradhan R, Nakagoshi N. 2008. Reproductive disorders in cattle due to nutritional status. Journal of International development and cooperation. 14 (1): 45-66.

Radisic B, Maticic D, Vluk D, Lipar M, Balić IM, Ditko B, Smolec O, Orak A, Capak H, Kos J. 2012. Measurements of healthy and pathologically altered hooves, their interrelation and correlation with body mass in Simmental breeding bulls. Veterinarski arhiv. 82 (6): 531-544.

Rahmawati D, Widyaningrum Y, Sulistya TA. 2015. Perlakuan Exercise pada Sapi Jantan PO terhadap Peningkatan Kualitas Semen. Prosiding Seminar Nasional Teknologi Peternakan dan Veteriner 2015. hal $81-85$

Stoddard GC, Cramer G. 2017. A Review of the Relationship Between Hoof Trimming and Dairy Cattle Welfare. Veterinary Clinics of North America: Food Animal Practice. 33 (2): 365-375
Simmental - Associationof Slovak Spotted Cattle Breeders - Cooperative. 2014.

http://www.Simmental.sk/home.html diakses 15 Juli 2017

Singh S, Bhakat M, Mohanty TK, Kumar A, Gupta AK, Chakravarty AK, Singh P. 2015. Sexual behavior and its relationship with semen quality parameters in Sahiwal breeding bulls. Veterinary World. 8: 745-749

Siregar SB. 2008. Penggemukan Sapi. Edisi Revisi. Depok (ID): Penerbit Penebar Swadaya. Cetakan XVII.

Sugeng B. 2002. Beternak Sapi Potong. Jakarta (ID): Penebar Swadaya.

Suprijati 2013. Seng organik sebagai imbuhan pakan ruminansia. Wartazoa. 23 (3): 142-157

Susilorini ET. 2008. Budi Daya 22 Ternak Potensial. Jakarta (ID): Penebar Swadaya.

Telezhenko E, Bergsten C. 2005. Influence of floor type on the locomotion of dairy. Applied Animal Behaviour Science. 93: 183-197

Widodo W. 2002. Nutrisi Pakan Unggas Kontekstual. Malang (ID): Fakultas Peternakan-Perikanan Universitas Muhammadiyah. 